\title{
PEMANFAATAN ENERGI TERBARUKAN UNTUK PERANCANGAN SISTEM ROTARY DRYER PADA TAHAP PENGERINGAN DAUN TEH HIJAU DI KULONPROGO
}

\author{
Evrita Lusiana Utari \\ Jurusan Teknik Elektro, Fakultas Sains \& Teknologi Universitas Respati Yogyakarta \\ Jl. Laksda Adisucipto Km 6,3 Depok, Sleman, Yogyakarta 55281 \\ E-mail : evrita_lusiana@yahoo.com
}

\begin{abstract}
Indonesia receives solar energy with an average daily energy radiation per unit area per unit time of approximately 4.8 kilowatts / $\mathrm{m} 2$. Solar energy is one of the abundant, pollution-free, renewable energy sources and can be explored optimally. In the use of solar energy, it is necessary to develop a technology that is able to convert solar energy into the desired energy, namely electricity. The supply of electrical energy during the day can still be controlled by the solar cell, while at night it is controlled by a battery of $3600 \mathrm{mAH}$. This technology is known as solar cell or in the international world better known as solar cell or photovoltaic. Solar cell is a tool to convert solar energy into electrical energy. Photovoltaic is a technology that functions to convert or convert solar radiation into electrical energy directly. Single chip AT89S51 was used as a controller in the drying process electronically. It was an easier way to dry the clothes without having to wait for good weather. SHT sensors was used to detect room temperature and humidity in the dryer, push button switches were used as switches to determine the limits of temperature and humidity. Rotary dryer is a dryer which is shaped as a drum and rotates continuously which is heated by a heater. A rotary dryer consists of a rotating cylinder and is used to reduce or minimize moisture in the contents of the material and its handling is direct contact with the heat in the drying chamber. The design of the rotary dryer system for the drying process of tea leaves requires a setting temperature of $90^{\circ} \mathrm{C}$ with a drying time of 15-25 minutes. The energy needed to supply power in the rotary dryer is $1000 \mathrm{WH}$.
\end{abstract}

Keywords : Solar Cell, Rotary Dryer, Photovoltaic.

\section{PENDAHULUAN}

Sumber energi listrik merupakan salah satu kebutuhan dasar dalam mendorong aktivitas kehidupan manusia. Untuk membentu peningkatan ekonomi masyarakat perlu adanya penunjang yaitu alat penerangan, fasilitas umum, keperluan rumah tangga dan keperluan industry. Pemingkatan daya listrik Indonesia mencapai 87\% menurut Eko tahun 2015. Letak geografis Indonesia yang tidak semua daerah dapat terjangkau oleh Perusahaan Listrik Negara (PLN). Tingkat ketergantungan akan sumber pembangkit listrik yang utamanya berasal dari bahan bakar fosil sehingga energi listrik makin lama akan habis. Untuk itu perlu adanya sumber energi terbarukan yang perlu dimanfaatkan dengan optimal yaitu tenaga surya, tenaga air,dan tenaga angin. Salah satu energi terbarukan yaitu sinar matahari tersebut sangat bagus dikarenakan letak geografis Indonesia yang berada didaerah khatulistiwa memiliki potensi penyinaran yang cukup memadai. Energi surya tersebiut dapat menyinari selama 12 jam per hari, untuk tiap tahunnya, dengan intensitas yang lumayan tinggi yaitu berkisar 4,8 $\mathrm{kWH} / \mathrm{m}^{2} /$ hari.

Tingkat kebutuhan energi yang semakin tinggi inilah yang dibutuhkan untuk industri, komersial, domestik, pertanian, dan penggunaan transportasi. Dimana kebutuhan energi yang ada saat ini, sebagian besar terpenuhi oleh energi bahan bakar fosil seperti minyak bumi, batubara dan gas alam. Sehingga tingkat persediaan energi yang ada saat ini semakin berkurang. Hal tersebutlah membutuhkan inovasi baru atau energi alternatife sebagai sumber daya yang tak terbatas, untuk memenuhi kebutuhan energi masyarakat di masa yang akan datang. 
Solar Sel merupakan perangkat yang dapat mengubah energi cahaya matahari menjadi energi listrik dengan menggunakan fotovoltaik. Solar Sel adalah teknologi energi yang bersifat langsung. Sumber energi listrik ini diciptakan dengan cara menerima cahaya langsung dari matahari dan memunculkan efek fotovoltaik.

Dalam perkembangannya pemanfaatan energi terbarukan di Indonesia untuk menggantikan energi konvensional seperti pembangunan PLTU, PLTS dan PLTA yang menggantikan pembangkit listrik berasal dari bahan bakar minyak dan batu bara. PLTS salah satu energi yang relatif sangat sederhana dibandingkan dengan jenis pembangkit listrik lain atau konvensional, namun karena teknologi ini baru berkembang, prosesnya terlihat rumit dan asing. Tidak semua peralatan PLTS terdiri dari sistem dengan perangkat elektronik, sehingga pemasangannya bersifat plug and operate. Dalam memahami faktor penting dalam peralatan tersebut akan mempermudah dalam perencanaan suatu PLTS. Faktor - faktor yang harus direncanakan yaitu pola operasi PLTS dan terkoneksi atau tidaknya PLTS dengan jaringan listrik direncana lokasi (Cekdin,C. 2016). Faktor tersebut mempengaruhi pemilihan jenis dan kapasitas komponen utama yaitu modul surya (PV), inverter dan baterai (Djiteng, M. 2005). Tingkat kapasitas dari PLTS dinyatakan dengan kilowatt peak $(\mathrm{kWp})$. Dimana kapasitas inverter dinyatakan dalam $(\mathrm{kW})$ dan baterai dalam Amperehour (Ah) atau kWh

\section{TINJAUAN PUSTAKA}

Berdasarkan penelitian (Asti, N, 2009) tentang Efek Perbedaan Teknik Pengeringan terhadap Kualitas, Fermentabilitas, dan Kecernaan Hay Daun Rami (Boehmeria nivea L Gaud). Dalam sistem pengeringannya dengan cara (hay) guna pengawetannya daun. Dalam teknik pengeringannya menggunakan matahari terbuka, rumah kaca, dan oven. Dari hasil penelitian tersebut menunjukkan bahwa perbedaan dalam proses pengeringan yang menyebabkan perbedaan pada kandungan nutrien hay daun rami. Proses pengeringan ini dengan intensitas cahaya matahari 14 jam pada RK dan 21 jam pada KM dapat menghasilkan hay dengan kandungan BK $>86 \%$ atau KA $86 \%$ atau KA.

Pada hasil penelitian yang berjudul pengaruh suhu pengeringan dan ukuran potongan terhadap karakteristik teh kulit lidah buaya oleh (I wayan Agus dll) dalam penelitiannya lidah buaya yang merupakan bahan utama untuk pembuatan teh yang memiliki umur panen kurang lebih satu tahun, dan memiliki ukuran panjang $\pm 40 \mathrm{~cm}$ dan memiliki lebar $\pm 6 \mathrm{~cm}$. Dalam proses pembuatan daun lidah buaya dikupas menggunakan pisau. Setelah dikupas, selanjutnya kulit lidah buaya direndam dengan larutan air garam (5\%) selama 30 menit, kemudian dicuci hingga bersih dan dipotong menjadi 2 ukuran, yaitu yang memiliki luas $100 \mathrm{~mm}^{3}$ dan $200 \mathrm{~mm}^{3}$. Pada proses pengeringan yang dilakukan dengan oven pengering dengan 4 tingkatan suhu yang berbeda, yaitu $60^{\circ}\left( \pm 5^{\circ}\right)^{\circ} \mathrm{C}, 70\left( \pm 5^{\circ}\right)^{\circ} \mathrm{C}$, $80\left( \pm 5^{\circ}\right)^{\circ} \mathrm{C}$, dan $90\left( \pm 5^{\circ}\right)^{\circ} \mathrm{C}$ sampai kadar airnya mencapai $8( \pm 5) \%$.

Menurut penelitian yang berjudul "Perbedaan Teknik Pengeringan terhadap Kandungan Nutrien Brachiaria humidicola, Gamal (Gliricidia sepium) dan Rumput Raja (Pennisetum purpureum X Pennisetum thypoides)" oleh Sari N pada tahun 2012. Dalam penelitian ini memliki tujuan untuk mengevaluasi waktu dan teknik pengeringan yang efektif terhadap kandungan nutrien hijauan pakan Brachiaria humidicola, Gamal (Gliricidia sepium) dan rumput Raja (P. purpureum $\mathrm{x}$ P. thypoides). Hijauan pakan yang digunakan adalah Brachiaria humidicola, Gamal (Gliricidia sepium) dan rumput Raja (P. purpureum x P. thypoides) yang berasal dari Laboratorium Lapang Agrostologi. Dalam proses pengeringan yang dilakukan selama 7 jam hingga 21 jam dengan suhu 60 derajad. Untuk tingkat perubahan yang diamati berupa bobot kering, kehilangan bahan kering, bahan kering (BK), abu dan bahan organik (BO) serta protein kasar (PK). Hasil dari penelitian 
menunjukkan perbedaan teknik pengeringan yang berpengaruh pada fisik dan kandungan nutrien hijauan pada pakan yang dihasilkan. Untuk perbedaan teknik pengeringan dengan memberikan pengaruh terhadap tingkat pengeringan hijau pakan yang telah dihasilkan.

Berdasarkan penelitian yang berjudul prototype pemanfaatan solar cell sebagai sumber energi pada sistem otomatisasi lampu penerangan taman oleh (W. Yossie, 2013). Dalam sistem perancangannya lampu penerangan taman otomatis terdiri memiliki beberapa komponen yaitu catu daya, solar cell, sistem minimum, lampu dan LCD. Dalam prinsip kerja dari lampu penerangan taman otomatis yang berfungsi untuk mendeteksi adanya tegangan yang dihasilkan solar cell dalam pengkonversian energi. Besar tegangan tersebut digunakan sebagai acuan untuk menyalakan atau mematikan lampu secara otomatis.

Menurut Faslucky pada tahun 2012, tingkat optimalisasi untuk keluaran tegangan dari solar cell menggunakan lensa pemfokus cahaya matahari. Hasil dari studi optimalisasi tegangan keluaran yang bertujuan untuk mengetahui seberapa besar pengaruh penggunaan lensa terhadap peningkatan nilai intensitas cahaya dan tegangan yang dihasilkan oleh Sel Surya. Sel Surya yang digunakan jenis policrystal dan amorphous. Dalam proses penelitian pengukuran nilai intensitas, tegangan dan arus listrik guna menghitung nilai daya dan efisiensi dari sel surya.

Menurut penelitian dari (Utari, 2017), tentang induction heating yang merupakan penggabungan antara teknologi solar cell dengan induction heating yang manfaatnya untuk pengolahan produksi teh. Pada alat dengan proses menginduksi specimen dari panas hingga mencapai titik kering mencapai $100^{\circ} \mathrm{C}$. Daya yang dibutuhkan untuk menyuplai pemanas sebesar 300 Watt.

Menurut penelitian dari Noviansyah pada tahun 2013, yang mengambil penelitian tentang pemanas induksi kapasitas 200 Watt Pada proses pemanasan induksi diperlukan suatu alat yang mampu menghasilkan energi listrik yang besar agar dapat menginduksi dengan titik cair dari specimen ini mencapai $\pm 660^{\circ} \mathrm{C}$.

\section{METODELOGI PENELITIAN}

a. Pengambilan Data di Lokasi.

b. Mendesain Sistem Perancangan Alat.

c. Pemilihan Komponen Perancangan Alat.

d. Proses Perancangan Sistem Kendali Pada Alat Rotary Dryer dengan Sel Surya.

e. Analisis Hasil Pengujian Alat.

\subsection{Dasar Teori}

\subsubsection{Solar Cell}

Sel Surya adalah suatu perangkat yang dapat mengubah energi cahaya matahari menjadi energi listrik dengan menggunakan prinsip efek Photovoltaic. Efek Photovoltaic merupakan suatu fenomena munculnya tegangan listrik karena adanya kontak dua elektroda yang dihubungkan dengan sistem padatan saat mendapatkan energi cahaya. Sel Surya disebut juga dengan Sel Photovoltaic (PV). Efek Photovoltaic ini ditemukan oleh Henri Becquerel pada tahun 1839.

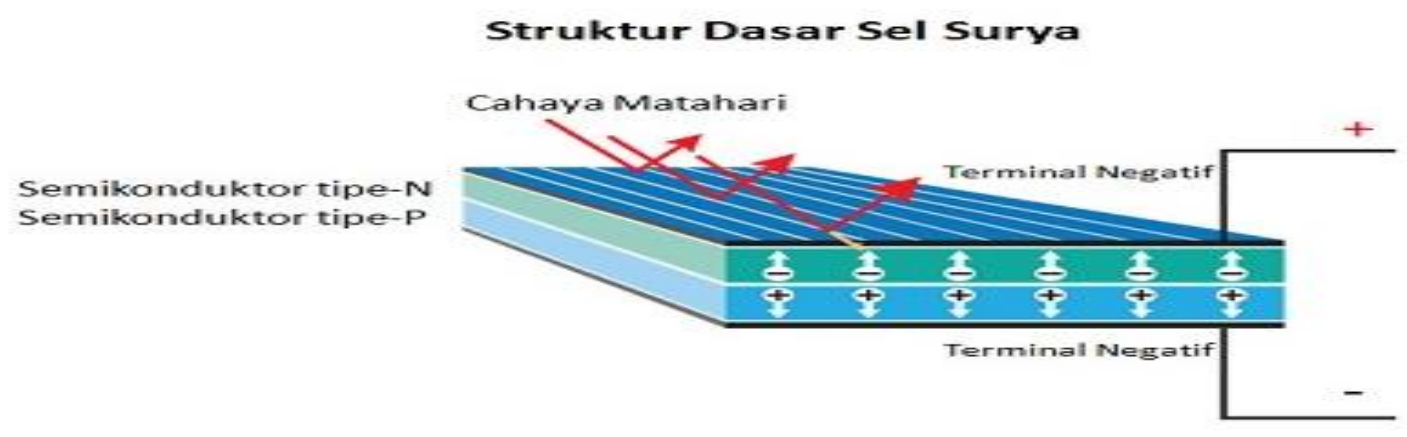

Gambar 1. Struktur Dasar Sel Surya.

(https://teknikelektronika.com/pengertian-sel-surya-solar-cell-prinsip-kerja-sel-surya) 


\subsection{Prinsip Dasar Teknologi Solar Cell}

Pada prinsipnya sinar matahari terdiri dari partikel sangat kecil yang disebut dengan foton. Ketika terkena sinar Matahari, foton yang merupakan partikel sinar Matahari meghantam atom semikonduktor silicon Sel Surya sehingga menimbulkan energi yang cukup besar untuk memisahkan elektron dari struktur atomnya. Elektron yang terpisah memiliki muatan Negatif (-) akan bebas bergerak pada daerah pita konduksi dari material semikonduktor. Atom yang kehilangan Elektron tersebut akan terjadi kekosongan pada strukturnya, kekosongan tersebut dinamakan dengan "hole" dengan muatan Positif (+).
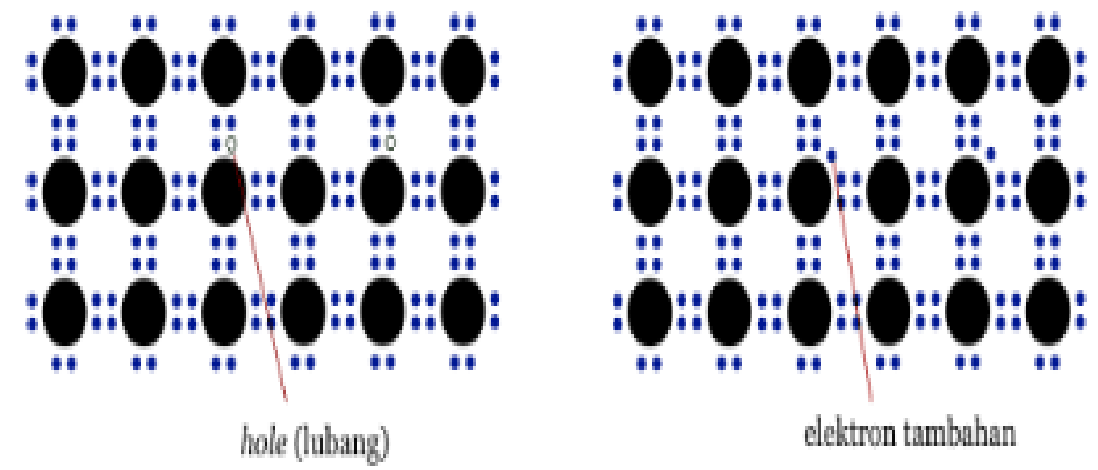

Gambar 2. Semikonduktor Tipe-P (Kiri) dan Tipe-N (Kanan).

(Ady Iswanto, Staf Divisi Riset 102FM ITB, 2008)

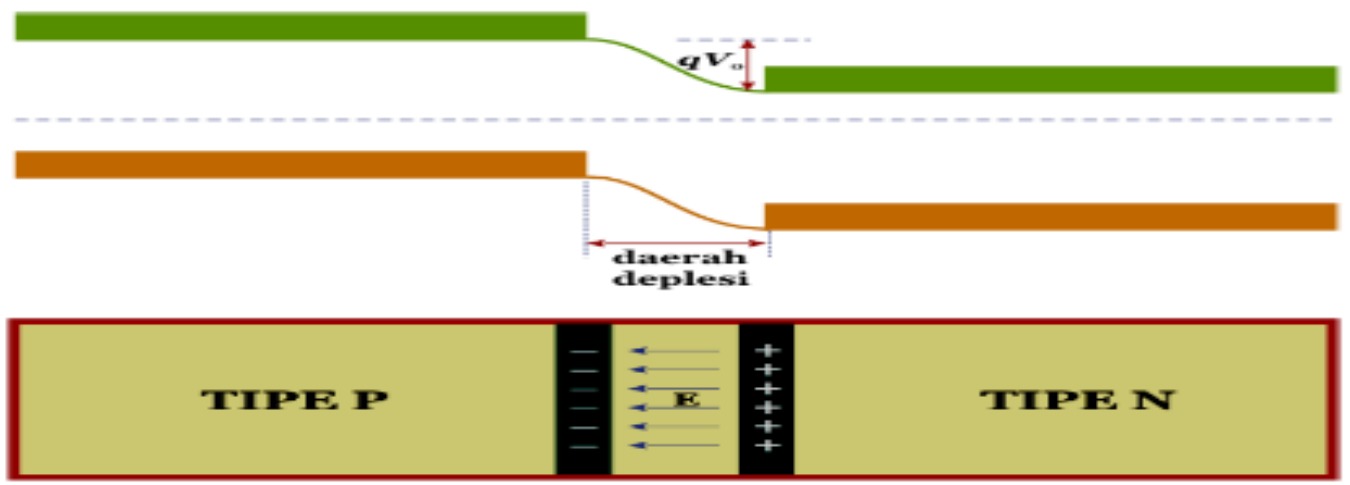

Gambar 3. Diagram Energi Sambungan P-N Munculnya Daerah Deplesi (Ady Iswanto, Staf Divisi Riset 102FM ITB, 2008) 


\subsection{Maximum Power Point Tracking (MPPT)}

Power Point Tracking yaitu sebuah alat yang memiliki sistem elektronik yang dioperasikan pada sebuah panel photovoltaic (PV). MPPT memiliki tegangan masukan baterai 12 volt hingga 48 volt. Tingkat efisiensi MPPT lebih baik dibandingkan PWM. Jenis MPPT digunakan untuk Sel Surya minimal $1000 \mathrm{WH}$ sedangkan untuk daya dibawah $1000 \mathrm{WH}$ dapat menggunakan PWM.

\subsection{Inverter}

Alat Inverter adalah Alat yang memiliki rangkaian elektronika daya yang digunakan untuk mengkonversikan tegangan searah (DC) ke suatu tegangan bolak-balik (AC). Jenis - jenis inverter DC ke AC berdasarkan jumlah fasa output inverter dapat dibedakan dalam inverter 1 fasa, yaitu inverter dengan output 1 fasa dan Inverter 2 fasa, yaitu inverter dengan output 3 fasa.

\subsection{Komponen Pemanas / Pengering}

Komponen pemanas yang digunakan adalah jenis Rotary dryer. Rotary dryer atau bisa disebut drum dryer merupakan alat pengering yang berbentuk sebuah drum dan berputar secara kontinyu yang dipanaskan dengan tungku atau gasifier. Alat rotary dryer terdiri dari sebuah silinder yang berputar dan digunakan untuk mengurangi atau meminimalkan cairan kelembaban isi materi dan penanganannya ialah kontak langsung dengan gas panas di dalam ruang pengering.

Pada alat pengering rotary dryer terjadi dua jenis kontak yaitu kontak dengan bahan dengan dinding dan aliran uap panas yang masuk ke dalam drum. Pengeringan yang terjadi akibat kontak bahan dengan dinding disebut konduksi karena panas dialirkan melalui media yang berupa logam. Sedangkan pengeringan yang terjadi akibat kontak bahan dengan aliran uap disebut konveksi karena sumber panas merupakan bentuk aliran. (Mc.Cabe, 1985).
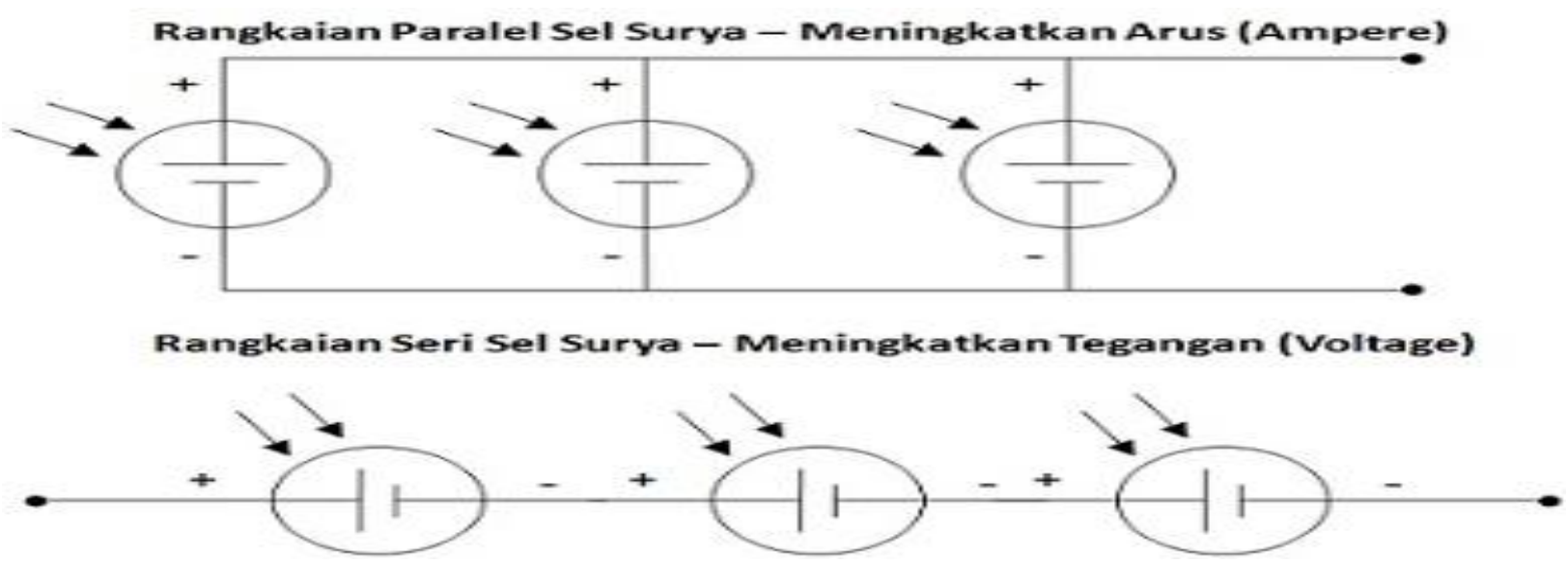

Gambar 4. Rangkaian Paralel dan Seri Sel Surya.

(https://teknikelektronika.com/pengertian-sel-surya-solar-cell-prinsip-kerja-sel-surya)

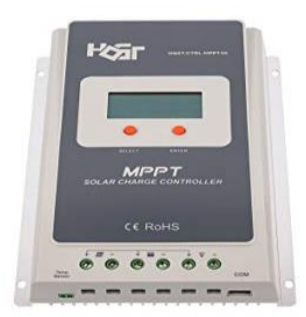

Gambar 5. MPPT 


\subsection{Jalannya / Alur Pikir Penelitian}

Adapun tahapan dalam penelitian ini diilustrasikan pada gambar 7. Dalam gambar terlihat proses awal mdiambil dari pengambilan data dilokasi, pemilihan perancangan alat baik perancangan dari sumber dayanya ataupun dari perancangan sistem kendalinya. Selanjutnya dilakukan pengambilan data dari hasil pengujian alat.

\subsection{Desain Perancangan Alat}

Desain perancangan alat menggunakan beberapa komponen dasar meliputi Solar Cell, MPPT, Aki, Inverter, Motor, Sistem Kendali, Temperatur, Rotary Dryer, dan LCD.

\subsubsection{Perancangan SHT 11}

Sensor SHT11 memiliki 4 pin yaitu GND, Vdd (5V), DATA, SCK (Clock). Pin Ground pada kaki 1 dihubungkan dengan ground pada mikrokontroler, sedangkan pada DATA yang ada pada kaki 2 dihubungkan pada kaki P3.0 dan pada kaki 3 yang merupakan Clock dihubungkan pada kaki P3.1. Untuk kaki 4 sebagai VDD untuk sumber arus yamg dialirkan pada SHT11. Dapat dilihat pada gambar 10.

\subsubsection{Perancangan Mikrokontroller}

Dalam perancangan rangkaian Mikrokontroler seri AT89S51 menggunakan konfigurasi pin mikrokontroler Pin RST. RST ini berfungsi sebagai masukan untuk melakukan reset terhadap mikro. Pin XTAL 1 dan XTAL 2 merupakan pin masukan untuk kristal osilator. Perancangan mikrokontroler dapat dilihat pada gambar 11.

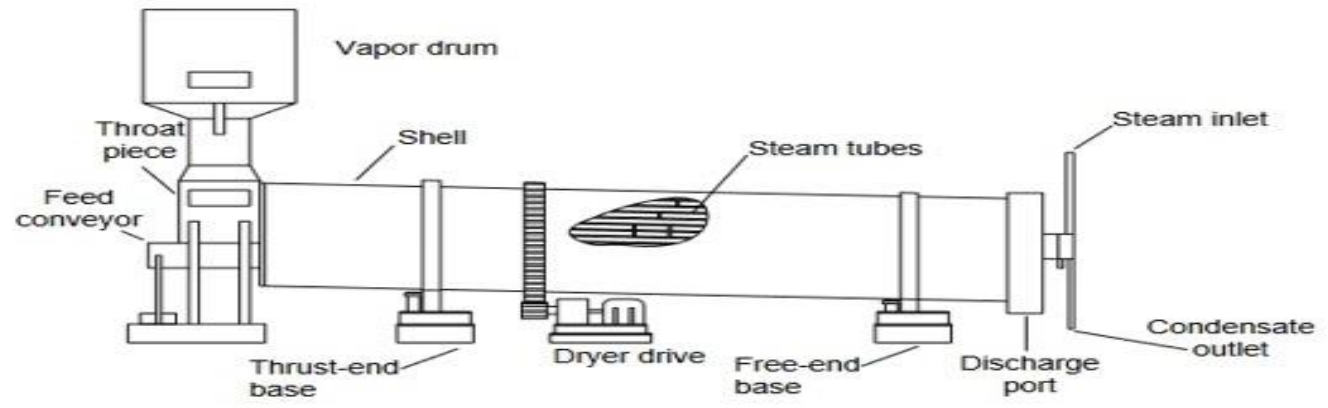

Gambar 6. Rotary Dryer.

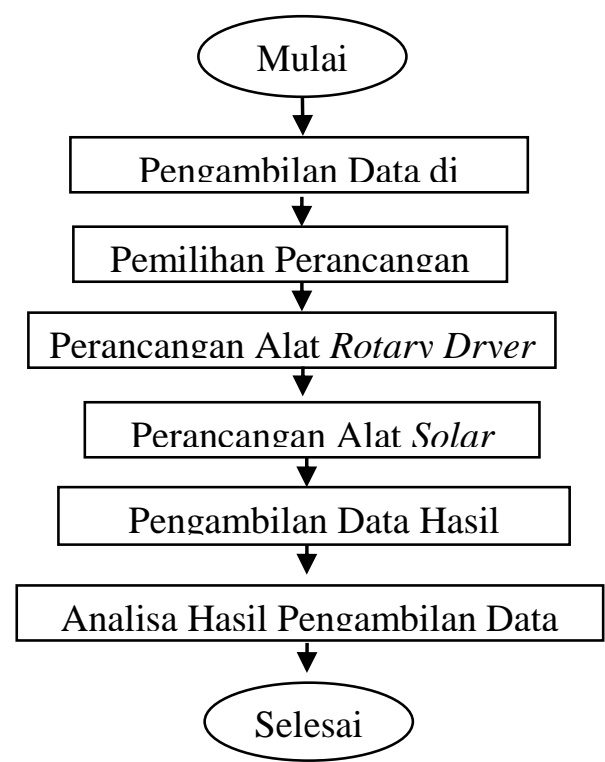

Gambar 7. Bagan Alur Penelitian. 


\subsubsection{Perancangan Sistem Kendali}

Pada perancangan sistem kendali terdapat pada gambar 9 .

\subsubsection{Rangkaian Push Button}

Pada rangkaian Push Button memiliki 3 saklar, yang mana saklar bertindak sebagai saklar program. Saklar pertama sebagai UP digunakan untuk menaikkan suhu dan kelembaban, saklar kedua sebagai DOWN untuk menurunkan suhu dan kelembaban, dan saklar yang dipilih sebagai SELECT digunakan untuk memilih tampilan. Rangkaian tersebut ditunjukkan pada gambar 12.

\subsubsection{Rangkaian Kipas}

Pada perancangan rangkaian kipas berfungsi untuk memperluas sebaran panas yang dihasilkan oleh pemanas. Rangkaian kipas terhubung langsung penguat dan selanjutkan dihubungkan dengan mikrokontroler. gambar 13 menunjukkan rangkaian kipas.

\subsubsection{Rangkaian LCD}

Rangkaian LCD berfungsi sebagai indicator penampil untuk hasil dari proses yang berbentuk text. Perancangan pada LCD dengan ukuran $2 \times 16$. Dimana data yang rangkaian LCD terhubung dengan rangkaian mikrokokontroler yang dapat dilihat pada gambar 14.

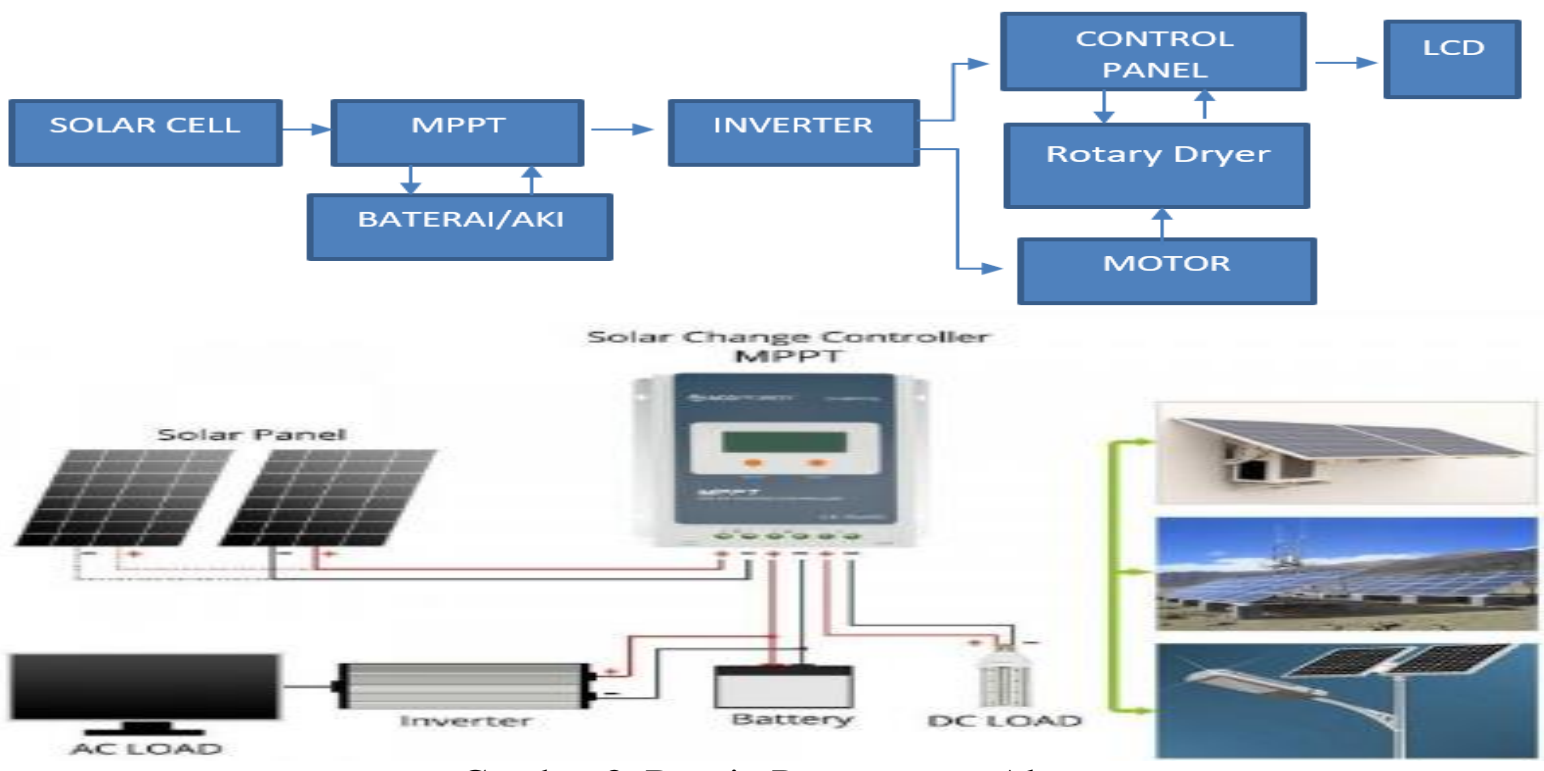

Gambar 8. Desain Perancangan Alat.

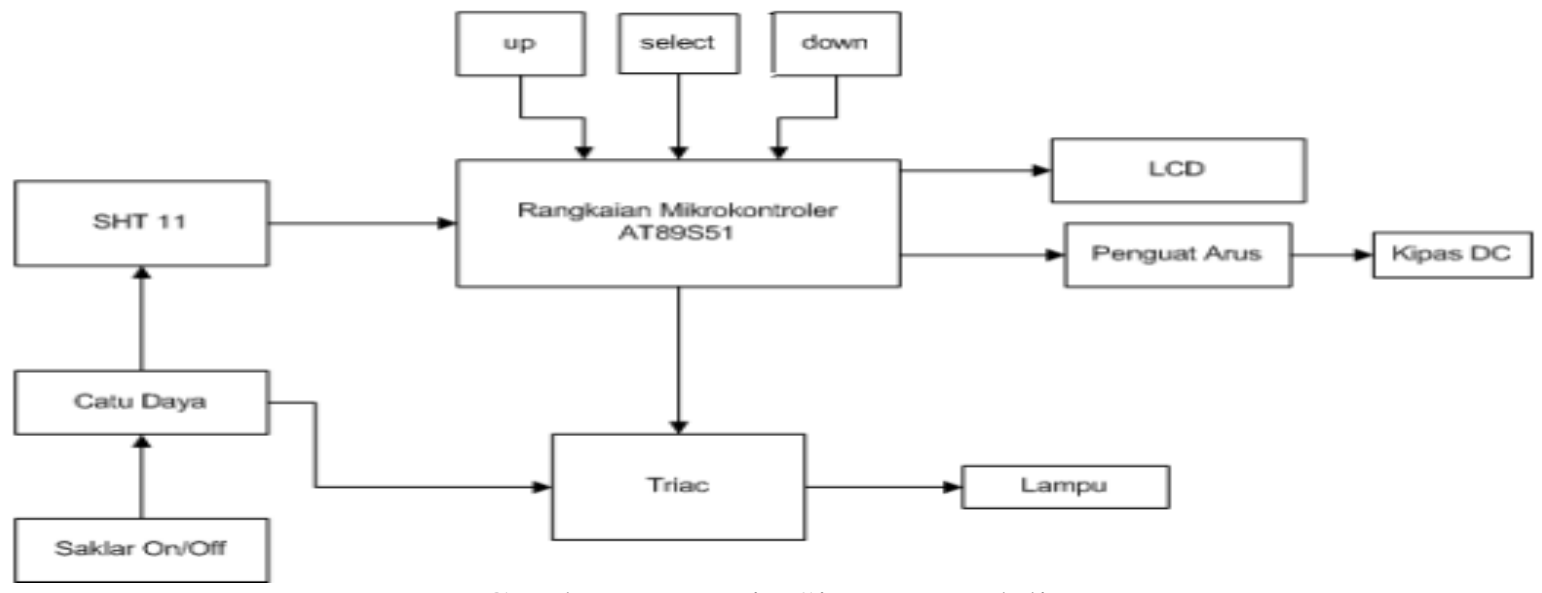

Gambar 9. Desain Sistem Kendali. 
Tabel 1. Analisa Hasil Perancangan Alat

\begin{tabular}{c|c|c|c|c|c|c}
\hline $\begin{array}{c}\text { No } \\
\text { Aki } \\
\text { (V) }\end{array}$ & $\begin{array}{c}\text { Tegangan } \\
\text { (Buah) }\end{array}$ & $\begin{array}{c}\text { Arus } \\
\text { (A) }\end{array}$ & $\begin{array}{c}\text { Daya Aki } \\
\text { (WH) }\end{array}$ & $\begin{array}{c}\text { Solar } \\
\text { Panel } \\
\text { (Watt) }\end{array}$ & $\begin{array}{c}\text { Estimasi } \\
\text { Max } \\
\text { Pemakaian } \\
\text { Waktu } \\
\text { (Jam) }\end{array}$ \\
\hline 1 & 12 & 8 & 7,2 & 691,2 & 250 & 3 \\
2 & 12 & 12 & 7.2 & 1036,8 & 500 & 5 \\
3 & 12 & 16 & 7,2 & 1382,4 & 500 & 6 \\
\hline
\end{tabular}

Tabel 2. Analisa Hasil Uji Pemanas

\begin{tabular}{c|c|c|c|c|c|c|c|c|c|c}
\hline No & \multicolumn{5}{|c|}{ Panas Matahari } & \multicolumn{5}{c}{ Alat Pengering } \\
\hline 1 & 35 & 43 & 29 & 53 & 24 & 22 & 21 & 23 & 21 & 21 \\
2 & 55 & 57 & 49 & 72 & 47 & 37 & 34 & 38 & 34 & 40 \\
3 & 91 & 92 & 95 & 87 & 75 & 56 & 44 & 54 & 65 & 56 \\
\hline
\end{tabular}

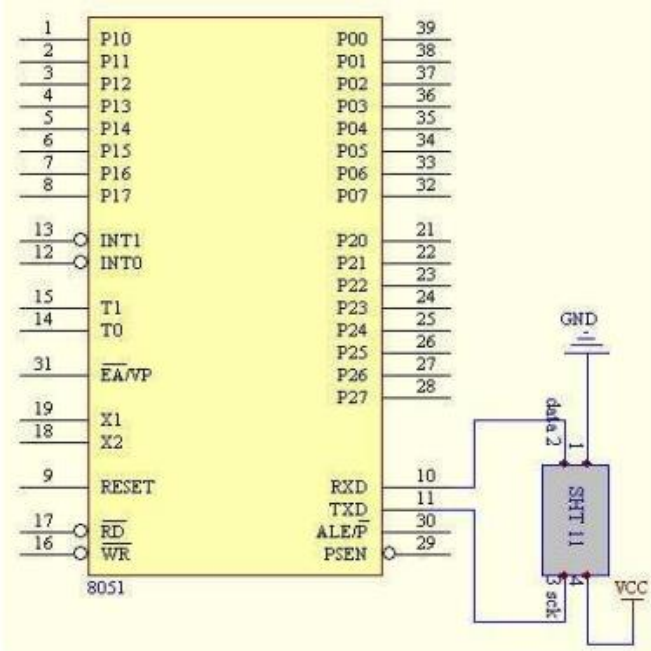

Gambar 10. Rangkaian SHT 11.

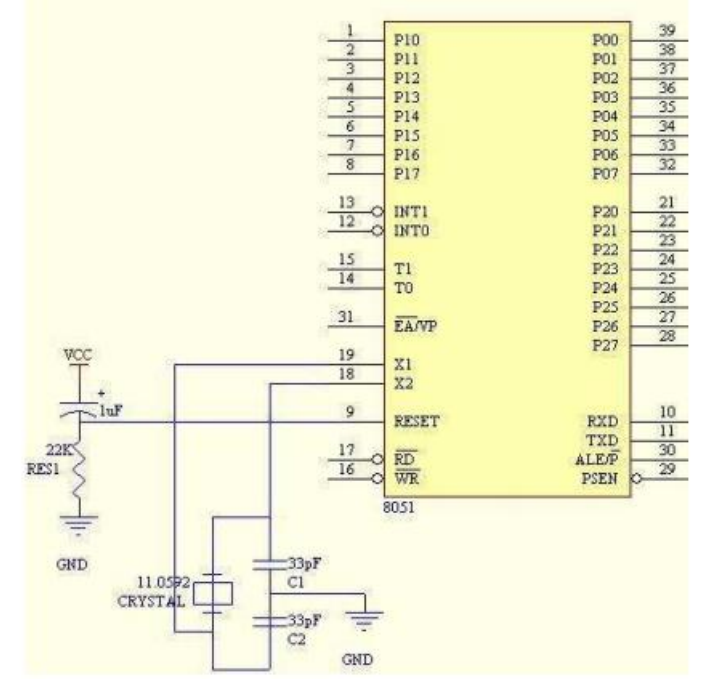

Gambar 11. Rangkaian Mikrokontroler. 


\section{HASIL DAN PEMBAHASAN}

\subsection{Pengolahan Data}

Pada analisa data yang dilakukan adalah dengan menghitung tingkat kebutuhan daya yang dikeluarkan oleh Sel Surya yang tersimpan dalam baterai / Aki yang akan digunakan untuk menjalankan peralatan lainnya melalui proses inverter untuk komponen yang menggunakan tegangan $\mathrm{AC}$ sedangkan untuk DC langsung diambil melalui baterai.
Data hasil pemanasan diambil dari daya yang dihasilkan oleh Sel Surya. Dalam prosesnya melakukan uji pada proses kendali memasukkan nilai dari suhu yang diinginkan. Selanjutnya pemanas mulai bekerja. Setelah pemanas bekerja kipas mulai berputar agar suhu panasnya bias merata.

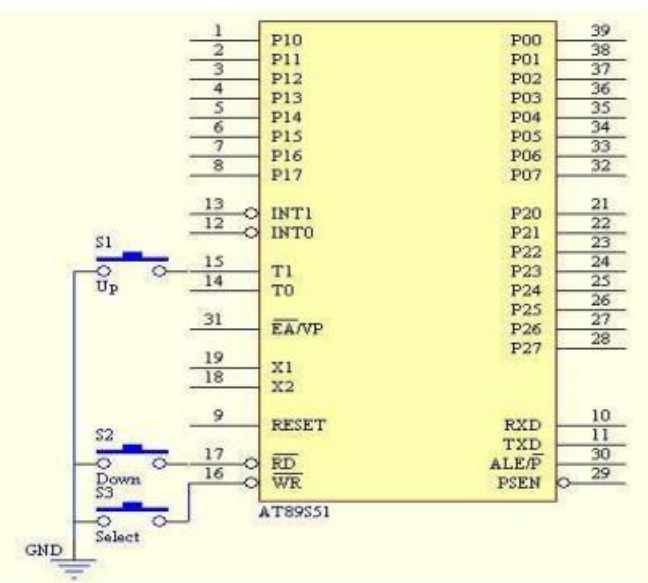

Gambar 12. Rangkaian Push Button.

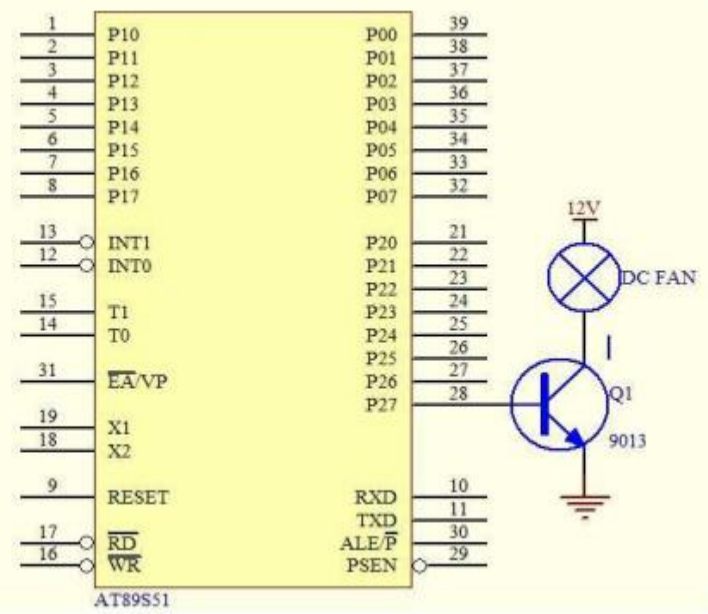

Gambar 13. Rangkaian Kipas. 


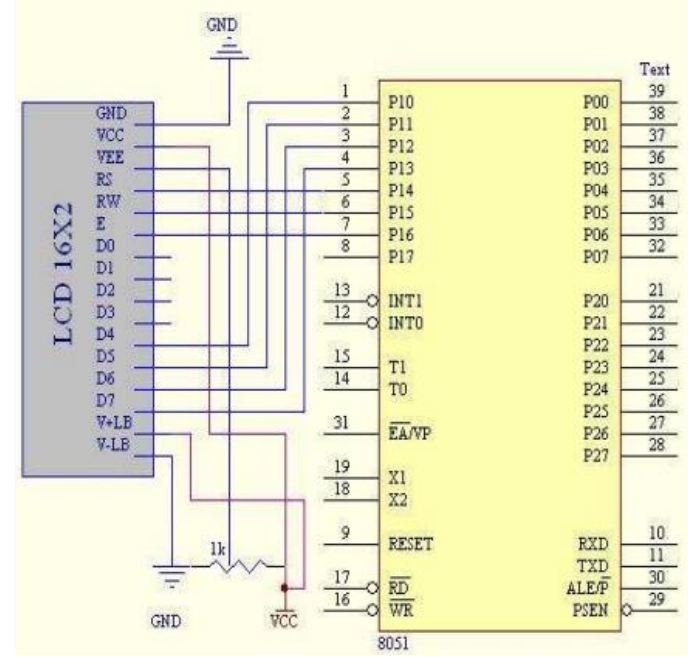

Gambar 14. Rangkaian LCD.

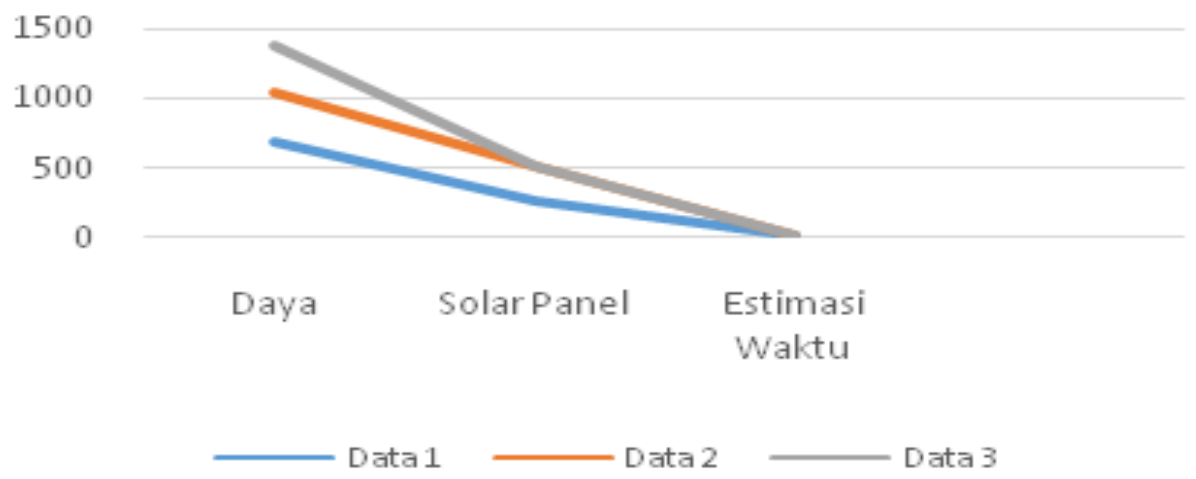

Gambar 15. Grafik Analisa Hasil Perancangan.

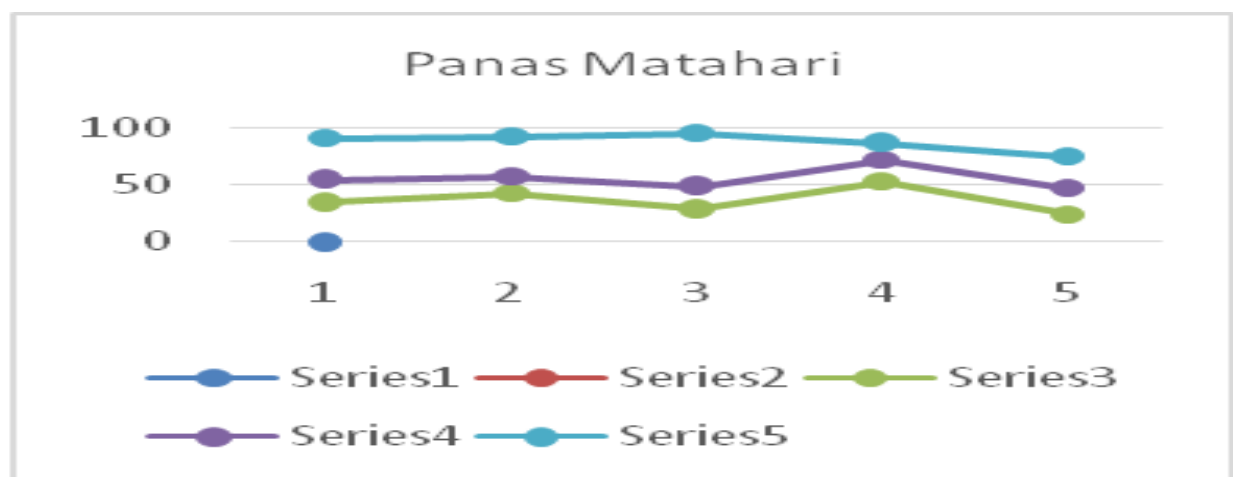

Gambar 16. Grafik Panas Matahari.

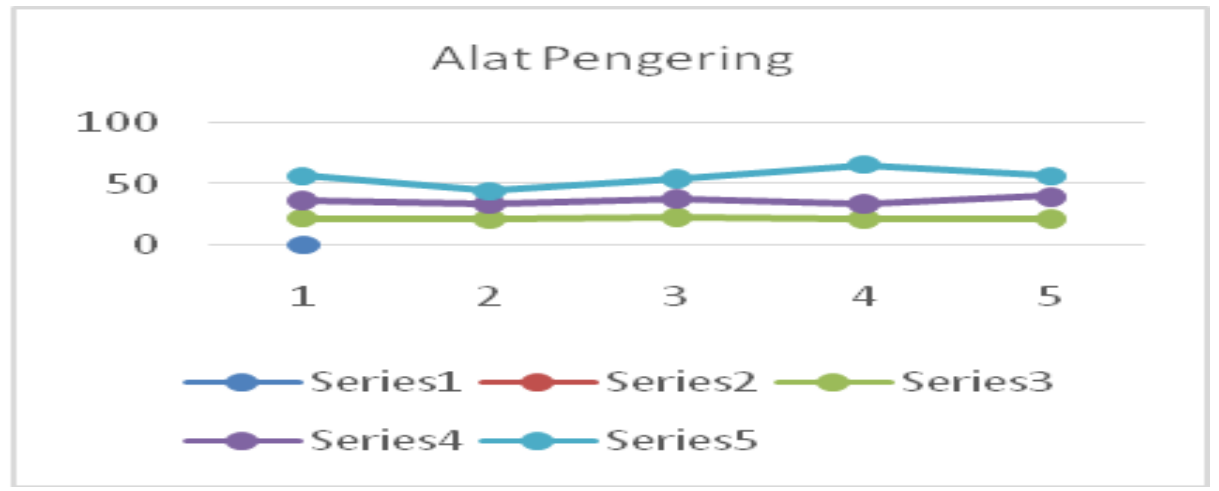

Gambar 17. Grafik Alat Pengering. 


\section{KESIMPULAN}

1. Komponen pemanas yang digunakan adalah jenis Rotary dryer. Rotary dryer atau bisa disebut drum dryer merupakan alat pengering yang berbentuk sebuah drum dan berputar secara kontinyu yang dipanaskan dengan tungku atau gasifier. Alat rotary dryer terdiri dari sebuah silinder yang berputar dan digunakan untuk mengurangi atau meminimalkan cairan kelembaban isi materi dan penanganannya ialah kontak langsung dengan gas panas di dalam ruang pengering. Perancangan sistem rotary dryer untuk proses pengeringan daun teh, dibutuhkan suhu pengaturan $90^{\circ} \mathrm{C}$ dengan waktu pengeringan $15-25$ menit. Energi yang dibutuhkan untuk mensupply daya pada rotary dryer sebesar $1000 \mathrm{WH}$.

2. Dari hasil Analisa perancangan alat bergantung dengan tingkat kebutuhan Daya pada pemanas untuk sangrai daun teh. Suhu yang dibutuhkan antara 80 sampai dengan 100 derajad Celcius. Lama waktu pemanasan dibutuhkan kira-kira dalam waktu 3 jam.

3. Desain perancangan alat menggunakan beberapa komponen dasar meliputi Solar Cell, MPPT, Aki, Inverter, Motor, Sistem Kendali, Temperatur, dan Rotary Dryer. Dimana untuk sistem menggunakan komponen Sensor SHT 11, Mikrokontroler, kipas dan LCD.

\section{DAFTAR PUSTAKA}

Agus, Wayan I, Pengaruh Suhu Pengeringan dan Ukuran Potongan terhadap Karakteristik Teh Kulit Lidah Buaya, Universitas Udayana, Bali.

Asti, A., Efek Perbedaan Teknik Pengeringan terhadap Kualitas, Fermentabilitas, dan Kecernaan Hay Daun Rami (Boehmeria nivea L Gaud). Skripsi. Departemen Ilmu Nutrisi dan Teknologi Pakan. Fakultas Peternakan. Institut Pertanian Bogor., 2009.

Cekdin,C., Teori Singkat Teknik Elektro. Penerbit Andi Yogyakarta., 2016.

D.Q,Kern , Process Heat Transfer, International Student Edition ,M.C, Graw-Hill, International.

Djiteng, M., Pembangkit Energi Listrik. Penerbit Erlangga. Jakarta., 2005.

Faslucky., Optimalisasi Tegangan Keluaran dari Solar Cell Menggunakan Lensa Pemfokus Cahaya Matahari. Malang., 2012.

Grainger, dkk., Power System Analysis, Mc.Graw-Hill., 1994.

Holman, JP. Mcgraw-Hill series in Mechanical Engineering, Includes index. ISBN 978-0-07-3529363-ISBN 0-07-352936-2. 
Iswanto, Ady., Bahan Silikon Semikonduktor Tipe P dan Tipe N, Institut Teknologi Bandung., 2008.

Marpuah, Dwi., Pembuatan Prototipe Alat Pengering Pakaian Berbasis Mikrokontroler At89s51, Prodi D3 Ilmu Komputer, Universitas Sebelas Maret., 2010.

Mc.Cabe., Perpindahan Panas Konveksi, Departemen Teknik Kimia ITB., 1985.

Mentary, Dyan., Prinsip Kerja Freeze Dryer, Politeknik Sriwijaya, Palembang., 2015.

Novinasyah, R., Pemanas Induksi (Induction Heating) Kapasitas 200

Watt. Jurusan Teknik Mesin Universitas Gunadarma., 2012.

Nurmala. $\quad$ S., Perbedaan Teknik Pengeringan terhadap Kandungan Nutrien Brachiaria humidicola, Gamal (Gliricidia sepium) dan Rumput Raja (Pennisetum purpureum $x \quad$ Pennisetum thypoides). Skripsi. Departemen Ilmu Nutrisi dan Teknologi Pakan, Fakultas Peternakan, Institut Pertanian Bogor., 2012.

Owen, Bishop., Understand Electronic. Newnes, Oxford., 2004.

Purnomo \& Hari M., Konsep Dasar Teknik Elektronika Kelistrikan. Penerbit Alfabeta. Bandung., 2014.

Putra S, dkk., Perencanaan Pembangkit Listrik Tenaga Surya Secara Mandiri Untuk Rumah Tinggal. Prosiding Seminar Naional Cendekiawan. Universitas Trisakti. Jakarta., 2016.

Ramadhan SG, dkk., Perencanaan Pembangkit Listrik Tenaga Surya di Atap Gedung Harry Hartanto Universitas Trisakti. Prosiding Seminar Nasinal Cendekiawan. Universitas Trisakti.Jakarta., 2016.

Sari, N, Karakteristik Pengeringan Daun Jeruk Purut (Cytrus hystrix DC) Menggunakan Oven Microwave. Fakultas Teknologi Pertanian Universitas Jember., 2012.
Sari, N., Karakteristik Pengeringan Daun Jeruk Purut (Cytrus hystrix DC) Menggunakan Oven Microwave. Fakultas Teknologi Pertanian Universitas Jember., 2012.

Sranipur R., Dasar Perencanaan Pembangkit Listrik Tenaga Surya. Jurnal JETri volume 11 No 2 Februari 2014. Universitas Trisakti. Jakarta., 2014.

Sranipur R. Dasar Perencanaan Pembangkit Listrik Tenaga Surya. Jurnal JETri volume 11 No 2 Februari. Universitas Trisakti. Jakarta., 2014.

Utari, EL, Perancangan Alat Inducsion Heating Pada Pengolahan Teh Sangrai Dengan Teknologi Energi Terbarukan (Solar Cell). Jurnal Teknoin. Universitas Islam Indonesia., 2017.

Utari, EL. 2017. Perancangan Alat Inducsion Heating Pada Pengolahan Teh Sangrai Dengan Teknologi Energi Terbarukan (Solar Cell). Jurnal Teknoin. Universitas Islam Indonesia., 2014.

Yossie,W, Prototype Pemanfaatan Solar Cell Sebagai Sumber Energi pada Sistem Otomatisasi Lampu Penerangan Taman. Universitas Negeri Yogyakarta., 2013.

Yossie,W., Prototype Pemanfaatan Solar Cell Sebagai Sumber Energi pada Sistem Otomatisasi Lampu Penerangan Taman., 2013.

Zhulkarnaen,Y, Perancangan Dan Pembuatan Pemanas Induksi Dengan Metode Pancake Coil Berbasis Mikrokontroller Atmega 8535. Universitas Brawijaya. Malang., 2014.

Zhulkarnaen,Y., Perancangan Dan Pembuatan Pemanas Induksi Dengan Metode Pancake Coil Berbasis Mikrokontroller Atmega 8535. Universitas Brawijaya. Malang., 2014. 